
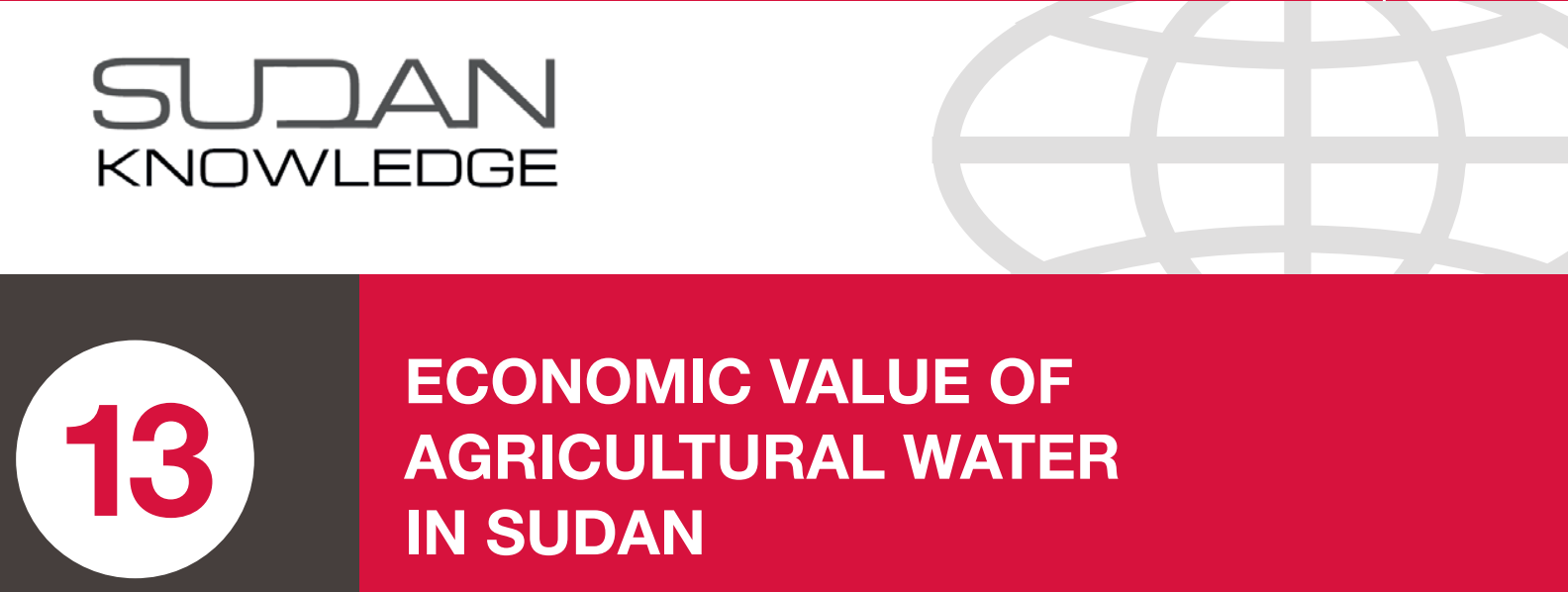

\title{
ECONOMIC VALUE OF AGRICULTURAL WATER IN SUDAN
}

\section{ELTIGANI E.B. ABDELGALIL}

Water Management and Irrigation Institute

University of Gezira, PO Box 20, Wad Medani, Sudan

Email: eltigani9@hotmail.com

\section{MOHAMED E. GALI}

Faculty of Agriculture

Department of Agricultural Economics,

University of Gezira,

PO 43, Wad Medani, Sudan

\section{ABSTRACT}

PURPOSE: The aim of this paper is to determine the value of water used in agriculture, the largest consumer of water, in Sudan.

METHODOLOGY: A CropWat model was used to determine the volume of water supplied for irrigation. Net revenue was calculated to determine the output from agriculture.

FINDINGS: The main results show that the net values of water ranged between $\$ 0.005 / \mathrm{m} 3$ and $\$ 0.001 / \mathrm{m} 3$ depending on the irrigation system used.

PRACTICAL IMPLICATIONS: These findings will help in setting the real value and cost of water in agriculture as the sector consuming the largest volume of water, and hence will help policy makers in developing decisions on agricultural water. 
SOCIAL VALUE: Valuation of water is one way of making users more aware of its value.

ORIGINALITY VALUE: This paper is the first to determine the value of agricultural water in the country.

KEYWORDS: value, water, agriculture, irrigation systems, Sudan

\section{INTRODUCTION}

There is an international consensus that water should be managed as a means of enhancing the sustainability of water resources. This cannot be achieved without integrating economics into the utilization of water, particularly in the agricultural sector. Incorporating the value of water into water management decisions is crucial for economic benefits and allocation of water resources. Rational decisions supporting water resource development, allocation, and use require measuring the value of water in alternative uses (Ward and Michelsen, 2002). The United Nations Conference on Environment and Development held in Rio de Janeiro in 1992, the World Summit on Sustainable Development held in Johannesburg in 2002, and the freshwater resources forum, documented that water should be treated as an economic good. Van der Zaag and Savenije (2006) stated that water should have a value in order to achieve two objectives, namely recovering the cost of providing the particular water service and giving a clear signal to the users that water is indeed scarce and should be used wisely. Creedy et al. (1998), and Duke et al. (2002) published materials on the value and cost of water, focusing on domestic use while Ward (2007) stated that economically efficient decisions supporting water resource development, allocation, conservation and protection may require measuring the value of water in alternative uses. Decision-makers need to know the exact value used in any water sector (domestic use, agriculture and industrial) to make the correct allocation decision.

Irrigation has long been described as a wasteful and low value water use (Perry et al., 2009), therefore policy makers seek to maximize productivity in terms of output per cubic metre of water. It is claimed that the charges made for irrigation water are far below the operation and maintenance cost of irrigation schemes. This is because of economic problems and practical difficulties in measuring and monitoring water use, and the dominant perception that water is a free good.

There is currently a low water fee in Sudan, causing an adverse impact on the irrigation systems and water use. Water has often been provided at subsidized prices or for free in many situations. Irrigated agriculture now occupies $18 \%$ of the total arable land in the world and produces more than $33 \%$ of its total agricultural production (Johansson et al., 2002). In Sudan, agriculture provides $90 \%$ of the raw materials for local industries, accounts for $30 \%$ to $40 \%$ of export earnings, and provides income and employment for the majority of the population (Omer, 2013). 
Estimating the real value of water used in agriculture will help policy makers to estimate real costs rather than only operation and maintenance costs.

The Sudan water policy of 1999 recognized the economic value of water (Omer, 2013); however, this is not strictly applied because the value of agricultural water was not previously estimated. For farmers to make enough income from agriculture, Robinson (2002) and Smith (2004) suggested providing sufficient water for irrigated agriculture at a low price. However, the real recovery fees according to the economic value of water will lead to sustainability of water use, particularly in agriculture as the sector consuming the majority of water. There are many technical Operation and Maintenance (O\&M) programmes adopted in irrigation schemes in Sudan with no significant progress in output; this is because recovery of operation and maintenance costs, and other irrigation services costs, is very low. This has resulted in huge losses of water, a reduction in growing areas annually, accumulation of silt in canals, reduction in productivity, and spread of water associated diseases.

The problem of water services charges and recovery are common in irrigated agriculture in Sudan. In the past, the Ministry of Water Resources did not receive sufficient payment for its services; therefore, the system was inadequately maintained that resulted in a poor quality of water supply services. Now, the irrigation system has collapsed, which is creating water shortage problems. Setting real value and real cost of water used in agriculture is an important instrument to break the vicious circle in irrigated schemes.

Scientists have used different methods to estimate the value of water. Gibbons (1986) used a net return of water approach for assessing the value of water used for agriculture; he calculated the value of water by subtracting variable production costs from gross revenues per hectare. Aylward et al. (2010) used a productivity approach to estimate the value of water in agriculture; they focused on cost/inputresponse functions. Colby (1989) used total revenues generated by irrigated crop production minus all production costs. In this work we mixed technical (CropWat) and economic (net return) concepts to value the agricultural water.

\section{THE OBJECTIVE}

The overall objective of this research is to determine the value of water used in agriculture under a gravity system in the Gezira Scheme, and spate irrigation systems in Gash Delta Agricultural Corporation in Sudan.

\section{ORGANIZATION}

This paper is organized in six sections. The first section (foregoing) includes the introduction and the objectives. The study area, which represents the location of Gezira and Gash schemes, is detailed in the second section. The third section deals 
with the methodology used in this paper. The results are presented in the fourth section, and discussed in the fifth section. The sixth and final section provides the conclusions and recommendations.

\section{STUDY AREA}

The study area includes three areas. These are the Gezira scheme, which is irrigated by a gravity system, the Gash Delta Agricultural Scheme (GDAS), which depends on flood irrigation, and the Gedarif area, which is a fully rainfall dependent system. All schemes lie in the dry zone and in the central clay plain in Sudan.

The Gezira scheme has an area of 0.88 million hectares. The scheme is supplied with irrigation water from the Sennar and Roseires Dams on the Blue Nile. Annually it consumes one-third $\left(6^{\star} 10^{9} \mathrm{~m}^{3}\right)$ of the Sudanese share from the Nile Waters Agreement of 1959. Topographically the land has a gentle slope from south to north at $15 \mathrm{~cm}$ per $\mathrm{km}$, and drops faster in the east-west direction towards the Blue Nile or the White Nile. The Gezira scheme has a clay soil, with a clay content of $56 \%$ in depths of between $0-65 \mathrm{~cm}$, and field capacity of $43 \%$ (Elias et al., 2001). The irrigation system is by gravity from the Sennar Dam through a huge network of canalization systems carrying water from the dam to the fields. The Gezira main canal continues northward with several branches from the Managil main canal. The distribution system then forms branches, major and minor canals down to field ditches carrying water to the fields (Barnett, 1977; Gaitskell, 1959; Fakki et al., 1982; Plusquellec, 1990). The crops grown are sorghum, groundnuts, cotton, wheat and vegetables. There are about 130,000 farmers in the Scheme.

The Gash Delta Agricultural Scheme is located in Kassala state, east of the Republic of the Sudan between latitudes 153031 and $160406 \mathrm{~N}$ and longitude 36 0526 and 360520 E (Abualgasim et al., 2011). The Delta stretches to about 110km North-East of Kassala town (Elkhalifa et al., 2003). The average annual rainfall ranges from $260 \mathrm{~mm}$ in the southeast to less than $100 \mathrm{~mm}$ in the northwest (IFAD, 2003). The Gash River (GR) dissipates in the terminal fan some $100 \mathrm{~km}$ north of Kassala town, where it provides moisture for natural forests, pasture and seasonal wetlands for crop production. Downstream from Kassala town, some of its flood water is diverted into canals that divert water into Messga. The Gedarif area is located in Eastern Sudan between Gezira and Kassala states and fully rain system dependent.

\section{METHODOLOGY}

This paper combines a CropWat model to determine the volume of water supplied for agriculture with economic concepts to determine the value of water used in agriculture; at the same time there is a comparison between the values of water used in various irrigation systems. Historical meteorological data from the study 
areas in Sudan (Gezira, Kassala and Gedarif) were utilized by the CropWat model to estimate the volume of water supplied for irrigation. Recorded data for the season 2012/2013 on the sorghum crop, including crop type, sowing dates, productivity, cost of cultivation, and value and cost of production, were collected. The sorghum crop was chosen because it is grown in all study areas under different irrigation systems. For data accuracy, primary data on the crop were collected directly from farmers in the field. Gross revenues for the sorghum crop were calculated, the cost of cultivation was subtracted, and then the net revenue was obtained. The net return of water was divided by the volume of water diverted for irrigation. The rain fed system was taken as pure rain fully dependent without any irrigation to accurately value the water supplied for irrigation. Values are listed in Sudanese pounds and then converted to USD (US dollars) to enable readers to make a direct comparison between the value of water across the globe. All currency conversions were applied after adjusting values for inflation, using exchange rates from the Central Bank of Sudan (USD 1 equivalent to SDG 5.8) at the time of the study.

Mathematically the following equation was used to determine the value of water in agriculture:

$$
\text { VWA }=\frac{\text { NVWI }- \text { NVWtI }}{\text { VWDI }}
$$

Where

VWA is the value of water in agriculture

NVWI is the net value of output with irrigation

NVWtl is the net value of output without irrigation

and VWDI is the volume of water diverted for irrigation: the volume of water in the denominator refers to the irrigation requirements and not to crop water requirements. Rainfall is not included in the volume of water in the denominator, but it is accounted for when the net value of output without irrigation is quantified. The net value of output was calculated using the following equation:

$$
\text { NVA = GVA - CC }
$$

Where

NVA is the net value of output

GVA is the gross value of output

CC is the cost of cultivation (cost of sorghum production). 


\section{RESULTS}

\section{THE VOLUME OF WATER DIVERTED FOR IRRIGATION}

The volume of water diverted for irrigation was calculated using a CropWat model, version 8.0 (Table 1). The results show that the volume of water supplied for irrigation is $4,374 \mathrm{~m}^{3} / \mathrm{ha} /$ year in the Gezira gravity system, and $3,752 \mathrm{~m}^{3} / \mathrm{ha} /$ year in the GDAS spate system.

\begin{tabular}{|l|l|l|l|l|}
\hline \multicolumn{3}{|l|}{ Table 1: CropWat output (supplied water for irrigation) } \\
\hline Scheme & $\begin{array}{l}\text { Type of } \\
\text { Irrigation }\end{array}$ & $\begin{array}{l}\text { Sorghum } \\
\text { water } \\
\text { requirements } \\
\left(\mathrm{m}^{3} / \mathrm{h}\right)\end{array}$ & $\begin{array}{l}\text { Total effective } \\
\text { rainfall }\left(\mathrm{m}^{3} / \mathrm{h}\right)\end{array}$ & $\begin{array}{l}\text { Irrigation } \\
\text { required }\end{array}$ \\
\hline $\begin{array}{l}\text { (Supplied } \\
\text { water) }\left(\mathrm{m}^{3} / \mathrm{h}\right)\end{array}$ & $\begin{array}{l}66.4 \\
- \text {-Maynamar }\end{array}$ & $17.54-$ Kenya & 27.70 & 29.44 \\
\hline Gezira Scheme & $\begin{array}{l}\text { Gravity } \\
\text { Irrigation }\end{array}$ & 6126 & 1958 & 4347 \\
\hline GDAS & Spate irrigation & 5259 & 1604 & 3752 \\
\hline Gedarif & Rain fed & 4951 & 3922 & 0 \\
\hline
\end{tabular}

\section{THE NET VALUE OF WATER}

It has been found that the gross values of output in irrigated systems is $\$ 358.6$ and $\$ 210.0$ per hectare (ha) in gravity systems and spate irrigation systems respectively, while the gross value of output in a rain fed system (without irrigation) is only $\$ 193.8 / h$. Thus, irrigation enables farmers to increase the gross value of output by $\$ 164.8 /$ ha and $\$ 16.2 /$ ha in gravity and spate systems respectively. Hence the volume of water diverted for the crop is $4,374 \mathrm{~m} 3 /$ ha per year in gravity systems, and 3,752 $\mathrm{m}^{3} /$ ha per year in spate systems (Table 1): irrigation makes an addition in net value of output by $\$ 20.6$ in gravity systems and $\$ 5.4$ in spate systems (Table 2). Therefore, the results give the value of water as $\$ 0.005 / \mathrm{m}^{3} / \mathrm{ha}$ in gravity systems and $\$ 0.001 / \mathrm{m}^{3} / \mathrm{ha}$ in spate systems (Table 2). It has been found that irrigation increases the net value of agricultural output by $11.8 \%$ in gravity irrigation systems and by $3.4 \%$ in spate irrigation systems. In addition, irrigation increases the cost by $78 \%$ and $21 \%$ in gravity and spate irrigation systems respectively. 


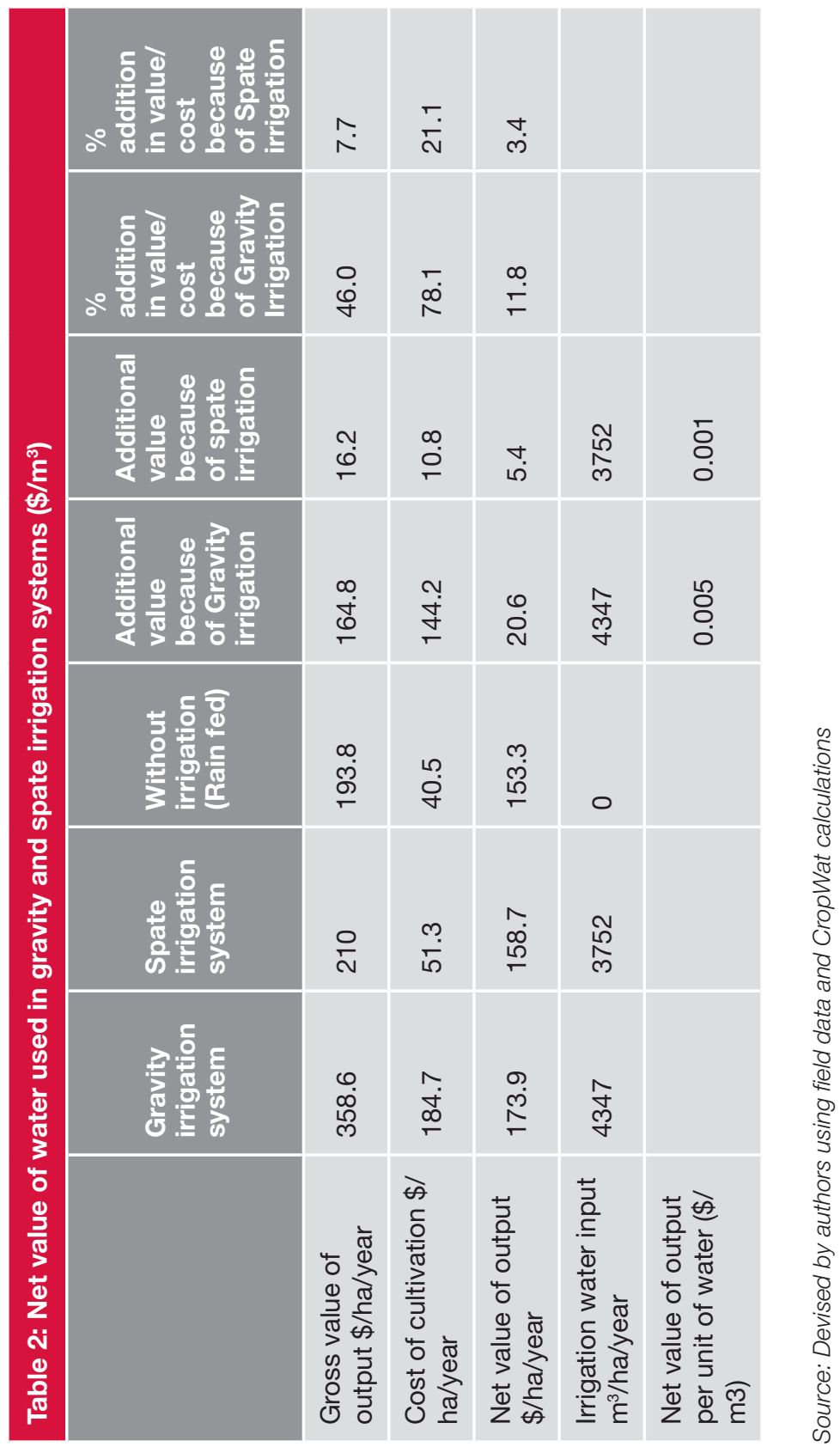




\section{DISCUSSION}

Sudan is currently utilizing $16.5 \times 10^{9} \mathrm{~m}^{3}$ annually from its share in the irrigated agriculture sub-sector (FAO, 2010). Currently, sorghum is widely cultivated in all agriculture sub-systems (gravity, spate and rain fed): the total area cropped with sorghum constitutes $30 \%$ of the total area. The irrigation requirement for the crop is high because rainfall in the arid region of Sudan is low (250-450mm/year) and evapotranspiration is high (150-200mm/year).

The values of water obtained are below the global range of $\$ 0.01 / \mathrm{m}^{3}$ to $\$ 2.0$ / $\mathrm{m}^{3}$. This is because of low productivity and the relatively high cost of cultivation. Irrigation increases the net value of agriculture and at the same time increases the cost of cultivation, particularly in gravity irrigation systems. This is because gravity irrigation systems require annual maintenance and operation to secure the water supply, while these activities are not always necessarily needed in spate systems. The result obtained is of vital importance because it will influence both decision makers and water users.

The calculated values can be used to reset irrigation water fees in the irrigated sector to reflect the real value. These values will contribute a great deal towards solving the historical problems of operation and maintenance costs in the irrigated sector in Sudan, as the World Bank (2000) reported that there is deterioration in the irrigation infrastructure, inefficiency in water distribution, water losses, and low recovery in irrigation water services costs in the Gezira Scheme.

With these results, this paper will support the message for the farmers that water has value and should be managed properly, as stated by Van Der Zaag and Savenije (2006). Attitudes and behaviour of users, and particularly farmers, need to be redirected because they feel that water is a free good. The result obtained can be used to evaluate changes in policies that would alter current farm water supplies or water use patterns as confirmed by Ward and Michelsen (2002). Exact and real water value is an effective tool for achieving efficiency in water used and financial sustainability of water supply agencies.

There is no policy for selling water in Sudan (Sudan Water Policy, 1999), but the farmers bear the irrigation services costs. The management fees are used to cover the management of the schemes conducted by irrigated schemes' managers. The irrigation fees used to cover the cost of water services to the Ministry of Finance and Economic Planning against the services provided by Ministry of Water Resources and Electricity, and schemes boards. Part of the cost goes to cover the cost of maintenance of canals. However, water fees are combined with administrative fees and collected together. This makes the value of water unclear.

According to the values of water estimated in this paper, a new set of water fees should be structured in the irrigated subsector. One of the irrigation management problems in Sudan is that the value and recovery rates of irrigation services are very low because of lack of scientific approaches in determining these values. This 
work will pave the way for a real value of water, which could significantly increase water use efficiency by releasing water for more effective irrigation, and allowing expansion of food production.

\section{CONCLUSIONS AND RECOMMENDATIONS}

The value of water used in agriculture is relatively low. Low productivity and high costs are behind the low value of water in the agricultural sector. A valuation of water used in agriculture as the major water consuming sector will help set real value and cost of water and hence correct decisions on agricultural water.

\section{REFERENCES}

Abualgasim, M.R., Csaplovice, E. and Biro, K. (2011): Mapping and monitoring land-cover/ land-use change in the Gash agricultural scheme (Eastern Sudan) using remote sensing. Conference on International Research on Food Security, Natural Resource Management, and Rural Development on the Margin. www.tropentag.de/2011/ abstracts/full/985.pdf Tropentag 2011, University of Bonn, 5-7 October 2011.

Aylward, B., Seely, H., Hartwell, R. and Dengel, J. (2010): The Economic Value of Water for Agricultural, Domestic and Industrial Uses: A Global Compilation of Economic Studies and Market Prices. Ecosystem Economics, available at http://www.ecosystemeconomics.com/ Resources_files/Aylward\%20et\%20al\%20(2010)\%20Value\%20of\%20Water.pdf (accessed 19 August 2014)

Barnett, T. (1977): The Gezira Scheme: An Illusion of Development, Frank Cass, London. Colby, B.G. (1989): Estimating the Value of Water in Alternative Uses. Natural Resources Journal, Vol. 29, pp.511-527.

Creedy, J., Van der Ven, J. and McKenzie, K.E. (1998): The demand for water by singlemetered and group-metered households. Australian Economic Review, 31(3), pp.203-210.

Duke, J., Ehemann, R. and MacKenzie, J. (2002): The distributional effects of water quantity management strategies: a spatial analysis. Review of Regional Studies, 32(1), pp.19-35.

Elias, E., Salih, A. and Alaily, F. (2001): Cracking patterns in the virisols of the Sudan, Gezira at the end of dry season. Journal of International Agro Physics, Vol. 15, No. 3, Institute of Agro Physics, Polish Academy of Sciences.

Faki, H., Osman, M. and Bailey, C. (1984): The effect of farm location on cotton yields and farm incomes in the Gezira Scheme in Sudan, In Fadl, O. and Charles, B. (Eds): Conference on Water Distribution in Sudanese Irrigated Agriculture: Productivity and Equity, University of Gezira, Wad Medani, Sudan.

FAO (2010): FAO's information system on water and agriculture AQUASTAT. Available at: http://www.fao.org/nr/water/aquastat/main/index.stm

Gaitskell, A. (1959): Gezira: A Story of Development in the Sudan, edited by K.D.D. Henderson, Faber and Faber, London.

Gibbons, D.C. (1986): The Economic Value of Water (Washington, DC, Resources for the Future). 
International Fund for Agricultural Development (IFAD) (2003): Gash sustainable livelihoods regeneration project, Formulation Report 1462-SD, Project Management Unit, Republic of Sudan and IFAD, Rome.

Johansson, R.C., Tsur, Y., Roe, T.L., Doukkali, R. and Dinar, A. (2002): Pricing irrigation water: a review of theory and practice. Water Policy, 4(2), pp.173-199.

Omer, A.M. (2012): Sustainable water resources management, future demands and adaptation strategies in Sudan, Journal of Environmental Science and Water Resources, Vol.1, No.7, p.151-168, Nigeria.

Omer, A.M. (2013): Conservation planning and management of limited water resources in arid and semi-arid areas as economic resources. Journal of Ecological Science Research (JESR) Vol. 1(2), pp.28-49, online: http://www.projournals.org/jesr.

Perry, C., Steduto, P., Allen, R.G. and Burt, C.M. (2009): Increasing productivity in irrigated agriculture: Agronomic constraints and hydrological realities. Agricultural Water Management, 96, pp.1517-1524.

Plusquellec, H. (1990): The Gezira irrigation scheme in Sudan: Objectives, design and performance. World Bank technical paper No 120. The World Bank, Washington D.C. USA.

Robinson, P.B. (2002): All for some; water inequity in Zambia and Zimbabwe. Physics and Chemistry of the Earth, 27(11-22), pp.851-857.

Smith, L.E. (2004): Assessment of the contribution of irrigation to poverty reduction and sustainable livelihoods. International Journal of Water Resources Development, 20(2), pp.243-257.

Sudan National Water Policy Document (SNWP) (1999): Ministry of Water Resources and Electricity. Khartoum, Sudan

Van Der Zaag, P. and Savenije, H.H.G. (2006): Water as an economic good: the value of pricing and the failure of markets. Research Report Series No. 19. UNESCO-IHE, Delft, The Netherlands.

Ward, F.A. (2007): Decision support for water policy: a review of economic concepts and tools. Water Policy, 9(1), pp.1-31.

Ward, F.A. and Michelsen, A. (2002) The economic value of water in agriculture: concepts and policy applications. Water Policy, 4(5), pp.423-446.

World Bank (2000): Sudan options for the sustainable development of the Gezira Scheme. World Bank reports, international documents unit. Washington DC, USA. 


\section{BIOGRAPHIES}

Eltigani Elnour Bashier Abdelgalil is an Assistant Professor of Water Management at the Water Management and Irrigation Institute of the University of Gezira. He holds a PhD in Water Management at the University of Gezira (2009), an MSc in Economics of Water Resources (2003), and a BSc in Agricultural Science from the Faculty for Agriculture and Natural Resources at the University of Gezira (1999). Currently, he is the Dean of Water Management and Irrigation Institute.

Mohamed Elgali is an Associate Professor of Agricultural Economics at the Department of Agricultural Economics, University of Gezira. He holds a PhD in Agricultural Economics from the University of Gezira (2007). Currently he is staff member and lecturer at University of Gezira, Sudan. 
